\title{
Sound System Nation: Jamaica
}

\author{
GRAHAM ST JOHN \\ UNIVERSITY OF QUEENSLAND
}

\section{from}

the

floor

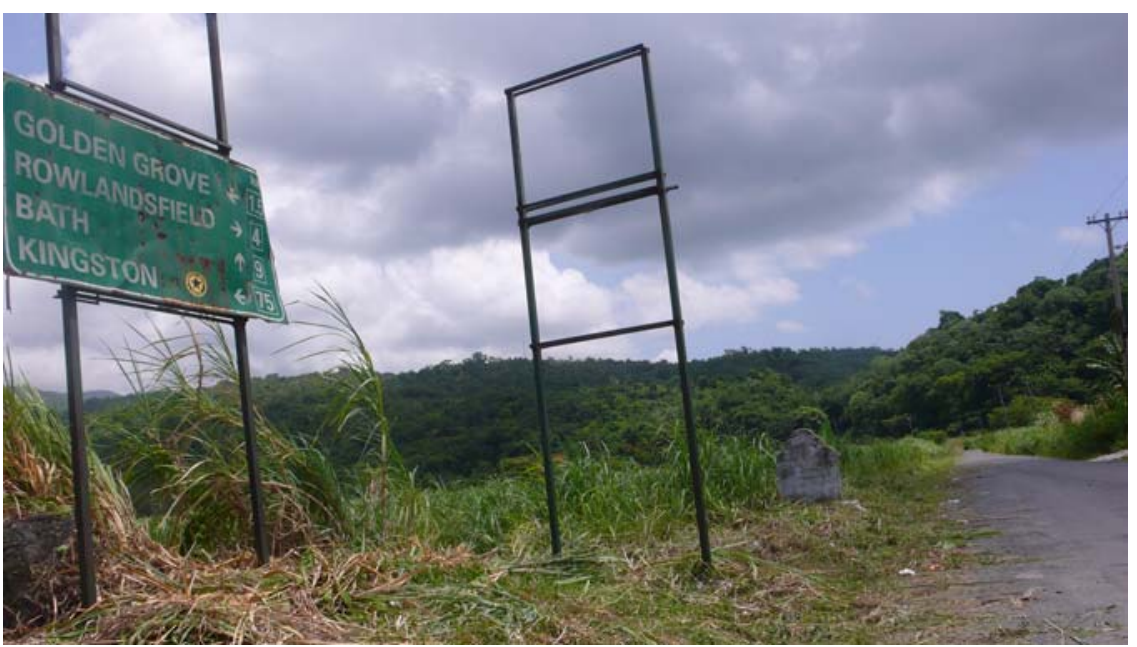

1. Photo by author

Several years ago, I started gathering interest in mobile initiatives committed to social and political causes in Australia called "sound systems". The likes of Labrats and other vehicles for the performance of postcolonial desires had been rallying the disaffected to wild and weird frontlines, pursuing, as techno-activist mover and shaker Pete Strong (aka Mashy P) once said, "a sound system for all”. Back then, I'd become excited by these proactive and convivial mobilisations. Responding to local ecological and humanitarian issues, and fed by developments in electronic music culture, a groovement was afoot.

Becoming interested in the roots of these developments, one path took me in the direction of the original spinners, the UK's Spiral Tribe, whose anarchist antics appealed to thousands of tekno-travelers and sonic squatters, attracting the law in the form of a four month and $£ 4$ million trial in 1994 that eventually saw Spiral Tribe participants acquitted of the charge of "conspiracy to cause a public nuisance". The Spirals then kicked off the European and worldwide freetekno movement - whose chief cultural expression is the teknival. 


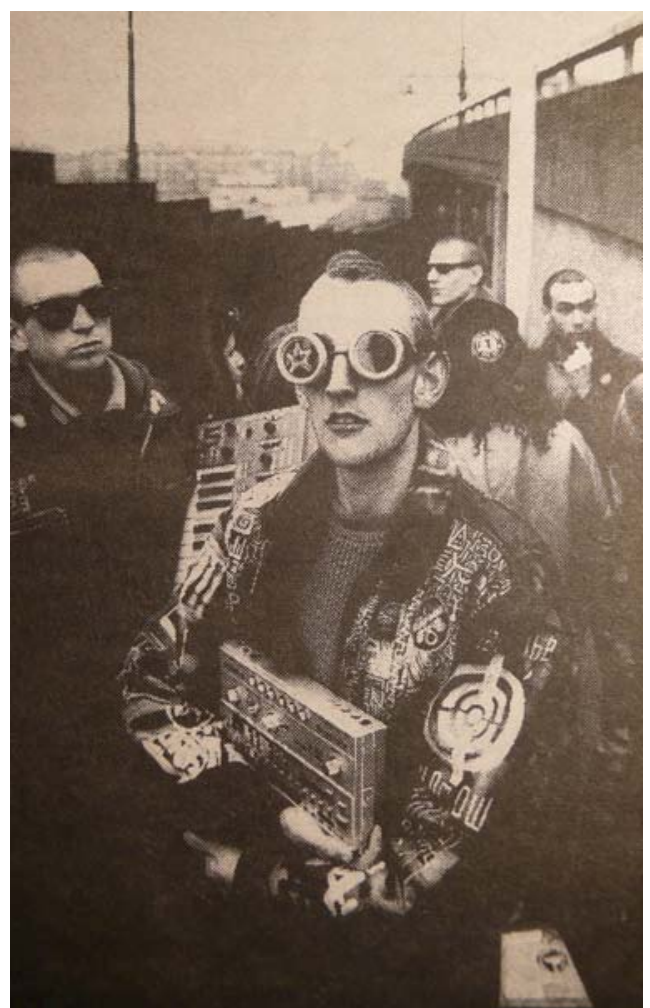

2. Simon Spiral with 303. Photo by Stefan Debatsalier, from New Music Express, 9 January 1993

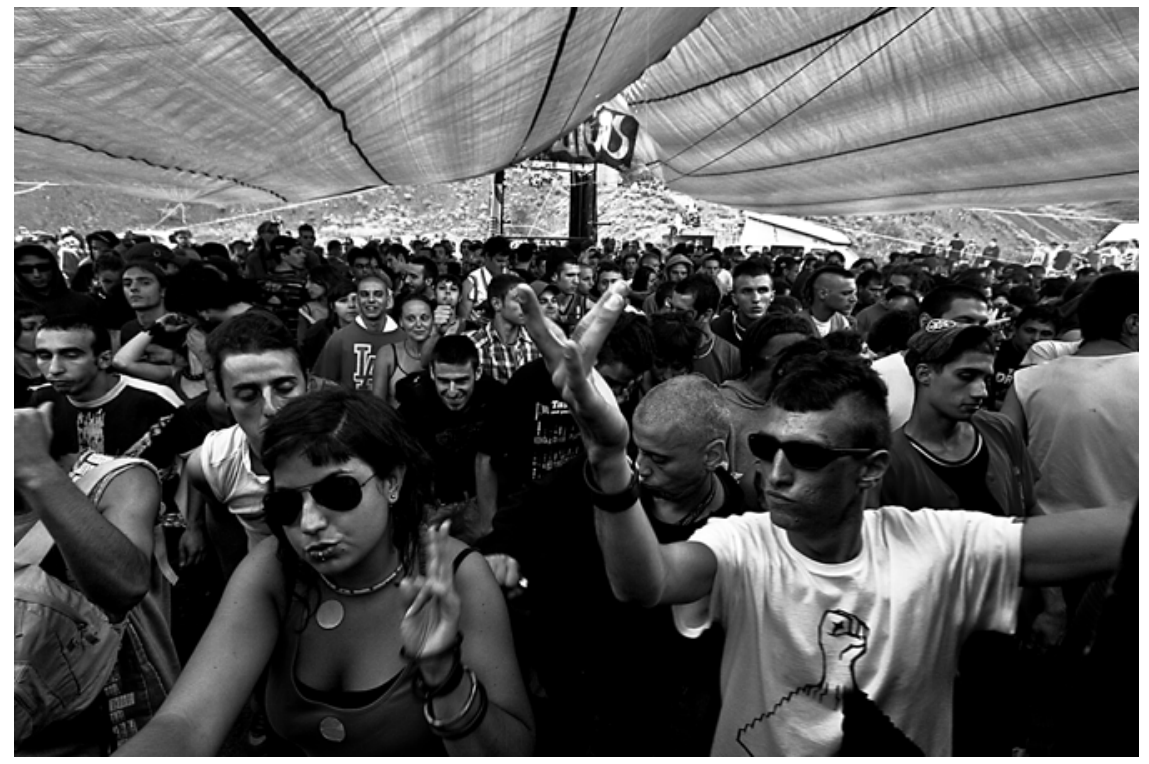

3. Out of System free party, Italy, July 2008. Photo by Alex Canazei (www.alexcanazei.com) 


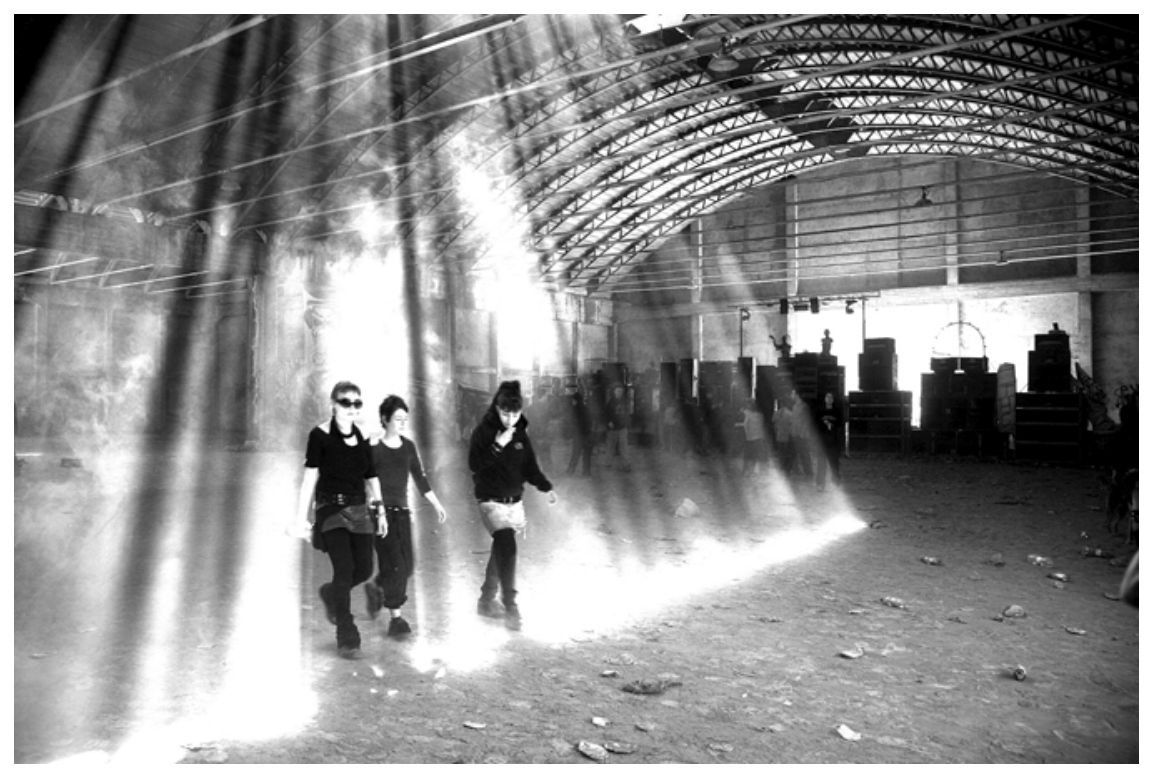

4. PasquaTek 2007. Photo by Alex Canazei (www.alexcanazei.com)

Although influenced by music and carnival traditions transferred from the Caribbean to the UK with the flows of immigrants from the 1960s, the non-Jamaican UK sound systems were generally vehicles for different "freedoms" than those pursued by participants in the African Diaspora. While Simon Jones (1995) and Enda Murray (2001) write about the appearance of these collectively owned cultural and technological resources in the UK and Australia, respectably capturing the transposition of JA to non-JA sound systems culture, the comparative study of the Jamaican and nonJamaican sound systems in Europe and elsewhere is mostly untouched territory. This research lacuna calls out for an understanding of the nature of "freedoms" sought, alongside the variant meanings of the phrase "sound system" which could certainly help by comparison with the traditional Jamaican dub sound culture as conveyed in Michael Veal's Dub: Soundscapes and Shattered Songs in Jamaican Reggae (2007). Tracing the evolution of dub reggae from Jamaica to London, it is anticipated that Christopher Partridge's book forthcoming with Equinox, Dub in Babylon, will help fill this cavernous gap.

Another path, then, took me to Jamaica where I knew lay the origins of the sound system development in Europe and around the world. Featuring the extemporaneous microphone controller or "toaster" (initially, also the "selector" or deejay), sound-reinforcement systems had been amplifying local concerns in Jamaica since the 1950s. So I quite readily jumped at the opportunity to travel to the land of riddim offered by the Crossroads in Cultural Studies conference held at the Mona campus of the University of West Indies in Kingston in early July 2008. Amid the dry heat and fugue triggered by sleep-interrupted nights in thin-walled campus apartments, I ran a panel on tension and change within electronic dance music cultures called "Uncertain Vibes". The panel attracted adventurous international scholars of EDMC. They were individuals seeking more from Jamaica than the cultural events laid on for conference delegates, which included a garden party reception at the Prime Minister's residence, and the performance from JA's number one sound system - Stone Love - in the tightly secured grounds of the university towards the end of the conference. 
Unlike most delegates who were bussed in daily from their plush hotel suites in Kingston, the panelists, along with many student delegates, occupied the cheaper gender-segregated on-campus lodgings in a compound patrolled by a legion of security personnel. Walking to the conference venue out of the compound each day, I was buffeted by the diverse sounds drifting across campus. The music seemed to be emanating from distant sports grounds and student residences. I recall the breeze carrying the refrain in Puff Daddy's "I'll Be Missing You" from a distant, yet remarkably audible, amplification system. Mixed with cricket commentary booming from portable radios belonging to maintenance crews, the music lifted me towards Mona Campus cultural centre. I had the distinct impression that parties were happening all around me, and a desire grew for contact, immersion and exposure beyond the campus compound.

During that week the UWI campus became a launching-pad for forays into Kingston. Prior to my arrival, Larisa Mann (aka dj Ripley), a graduate student in Law at Berkeley who'd traveled and worked in Kingston in 2007 (and kept a blog where, among other things, she offers her analysis of club DJ techniques and local dance culture) gave me the contact for Andrea Lewis, artist manager and chilled operator of Beat ' $n$ Track Tours who, with her rasta friend Bear, trucked a small group of us out to Trenchtown to Bob Marley's yard, the Boystown sportclub, then Lee "Scratch" Perry's house, and downtown Kingston to the Marcus Garvey museum and nearby off Orange St, famed for its record shops, for a steamed fish feast.

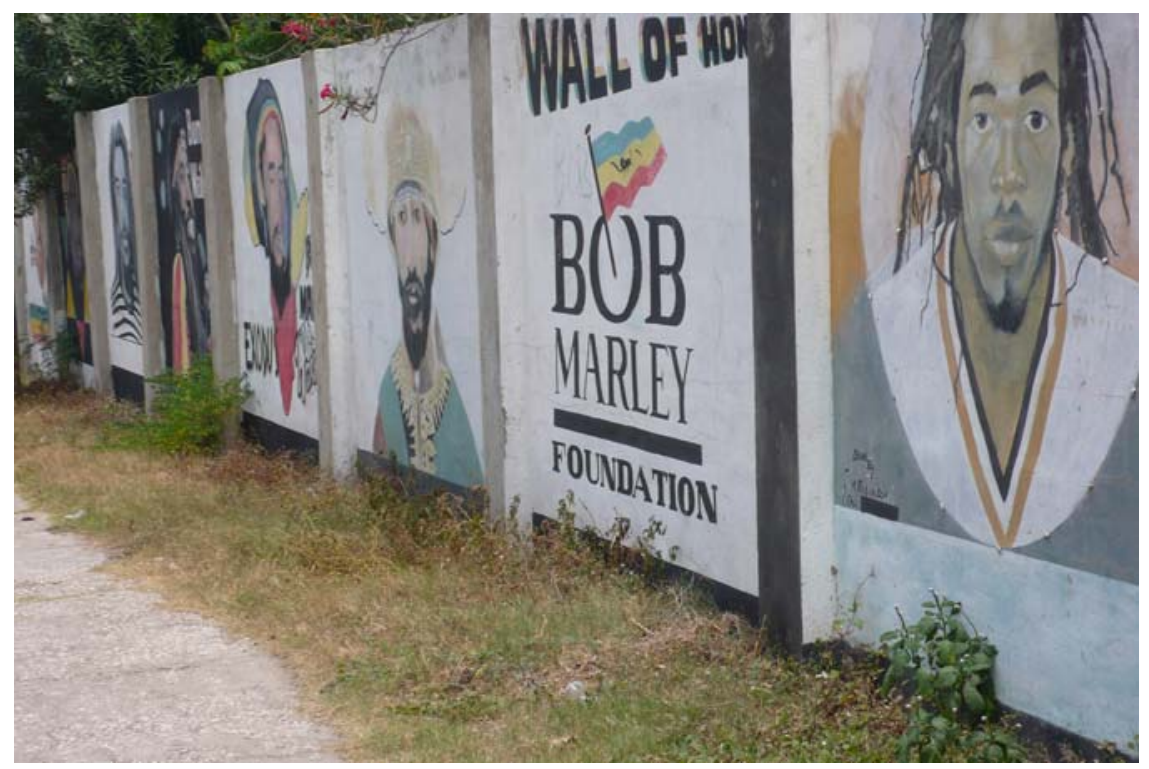

5. Trenchtown Murals. Photo by author

Some of us (including Anna Gavana, a dubstep DJ who, with DJplaneten, subsequently produced the Dancehall influenced track "Natty Maaga" using a chopped up voice sample from a 7-inch record acquired in Kingston) went on a night-rider with a young gang of chaperones to a Black Prince bashment in a carpark downtown. 


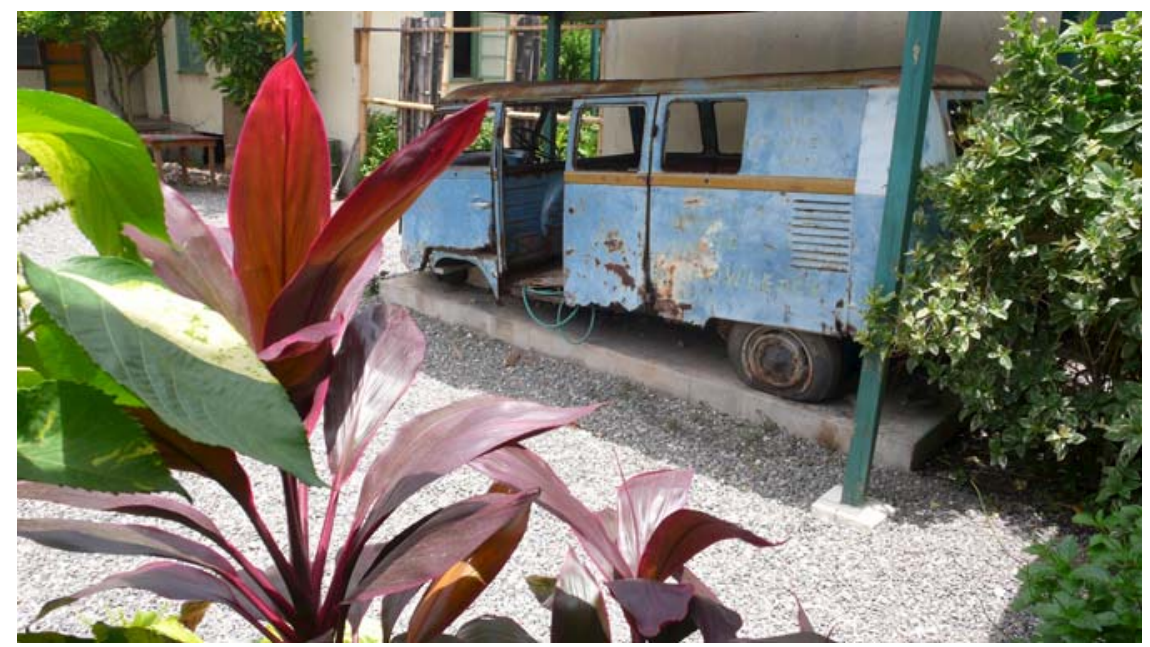

6. Bob Marley's Kombi at his yard in Trenchtown. Photo by author

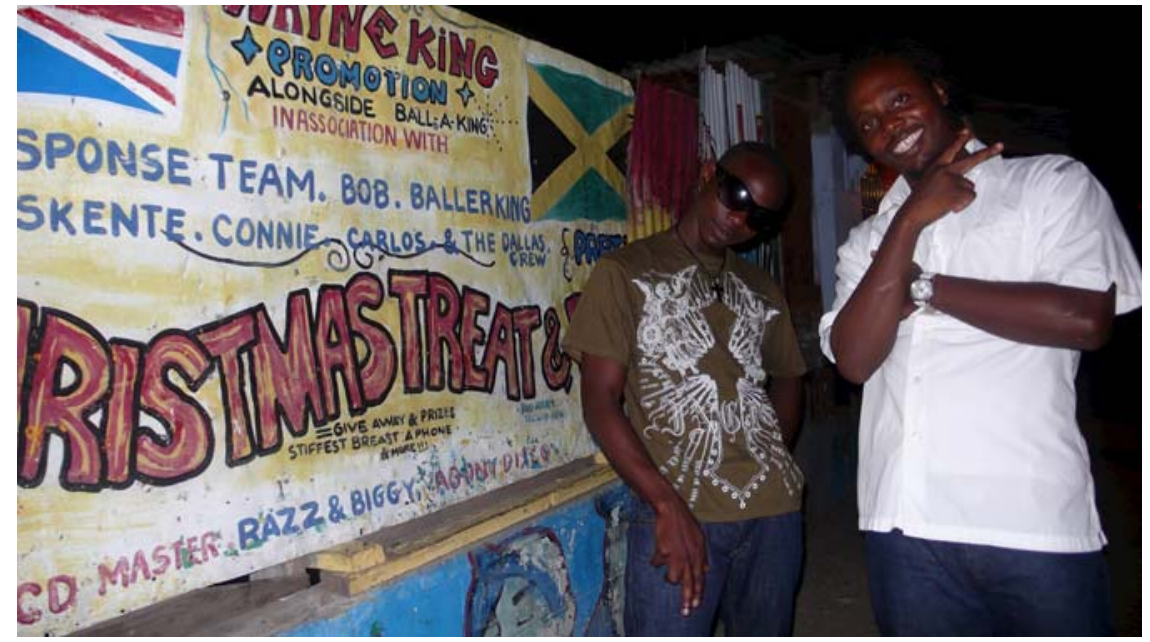

7. Kingston - en route to Black Prince with Damien and another of our guides at the Sherrif HQ. Photo by author

It was my first direct experience with the quality of the Jamaican sound systems. There were two walls of cabinets stacked high. Warmups included Toto's "Africa", startling to hear, and even more surprising was how good it sounded. I was broadsided by Toto, and enjoyed it. Our group (of four) were the only white people present, our chaperones looking after us. And we "looked after" them. Drinking Red Stripe, Stones, Appleton's, and rolling spliffs, the crowd grew but no one yet occupied the centre of the carpark. Since some of us were presenting the next day we had to leave before $1 \mathrm{am}$ - i.e. before all the action started. A couple of nights later, others disappeared into West Kingston to a party at the Stone Love HQ and a street party operated by the Mo' Money sound system, returning with wild reports of "daggering" and "Dutty Wine".

The following night, our local friend Bradley, whose mother held a stall at the conference, took us out to his favourite club and then the all-night rooftop venue at Cookies across the harbour from Port Royal. There, I got a sudden education. No, my 
friends hadn't been introduced to home grown wine. The Dutty Wine is a dance performed by women bent at the knees, with a rapid winding of legs and neck, body Lshaped and orchestrating all that rotation from their toes like ballerina seductresses. The place was dripping with it. What struck me most was the way young women were making themselves available for simulated gang-banging, willingly taken and publically pseudo-drilled by men in their cohort, or by total strangers, all fully-clothed, smiling and thrusting hips in close quarters, animated by the most powerful bass anywhere. Indeed the bass was the penetrative agent.

Perhaps my confusion had something to do with ignorance - the song "Dutty Wine" had catapulted dancehall artist Tony Matterhorn into fame a few years back, and even Beyoncé made a variation of this dance... Anyway, the athleticism wasn't exclusive to females poom-pooming their neighbours, as groups of young men would appear performing carefully rehearsed maneuvers, like what I later learned is called the "Nuh Linga".

\section{http://www.youtube.com/watch?v=_GFIFvjTmhs}

Wearing smooth soled shoes, they swept around the floor with incredible precision. These and a host of other dances evolve and circulate widely, perfected and modified every night across the country, including the popular "Scooby Doo", and even one intriguingly named the "Myspace".

And all this occurred under lights and on film. Video operators stalked the venue with their lights on high beam offering everyone the opportunity to vogue their moves (projected live on screens in the venue) for the benefit of all present, and presumably those absent - i.e. those viewing versions circulating on DVDs around the country. The shoots were directed by the MCs whose explicit and lurid encouragements were launched throughout the night in quickfire patois - setting up romances and other tales of "pussy stabbing", from slow grinds to frenetic encounters, as when, like vulturous vixens, girls in hot shorts circle and attack their target like this guy:

http://www.youtube.com/watch?v=nyb8ZHO9nIA

The entire performance seemed like a standoff between the Microphone Controllers and the Booty Controllers.

It was a steep learning curve. I knew of dancehall through passing mediators like Steve Bedlam (Bedlam sound system) and founder of reggae roots sound Negusa Negast, "Bashment" Bish, whose collaborative rig was imported from the UK to Australia for the Earthdream convoyage in 2000. I traveled with Bish and others like Jason from New York's Blackkat sound system to East Timor one year after the referendum, firing off embedded freak reports from the field including this piece from Dili. All of these guys were heavily influenced by the sound system tradition in Kingston, where, by the 1950s, "sound men" were using record players, amplifiers, and rare black American records, and when the "sound system" became the principal conduit for a subversive sphere of performance rooted in slave-era country dances and percolating in lowerclass black communities. Taking cues from post-WWII American R\&B, and early infused with dub-reggae and Rastafarianism, what became known as "dancehall" was a distinct Jamaican style by the 1980s, attracting controversy for its association with homophobia, bling and violence. 
After 2000, I poured over works like Norman Stolzoffs Wake the Town and Tell the People: Dancehall Culture in Jamaica, in which dancehall/sound system events are described as "the centre of the ghetto youth's lifeworld-a place for enjoyment, cultural expression and creativity, and spiritual renewal" (7). Later I came across Carolyn Cooper's Sound Clash: Jamaican Dancehall Culture at Large. Focusing on more than just the music and the DJs, Cooper conveys how dancehall is a vehicle for the lyrical and embodied articulation of what she identifies as "slackness", constituting, she writes, a "radical, underground confrontation with the patriarchal gender ideology and duplicitous morality of fundamentalist Jamaican society”. Dancehall achieves this, Cooper argues, in great part through dance performance in an "erogenous zone in which the celebration of female sexuality and fertility is ritualized" $(3,17)$. With her new book DanceHall: From Slave Ship to Ghetto, Crossroads conference organiser Sonjah Stanley Niaah has made an important contribution to this study, exploring the critical role of dancehall as a complex space for ritualised performance across Jamaican society.

But now I dropped the books and found myself deep in rhythm. Having left Kingston, I caught a small bus with a couple of Israeli friends Joshua and Frank to the

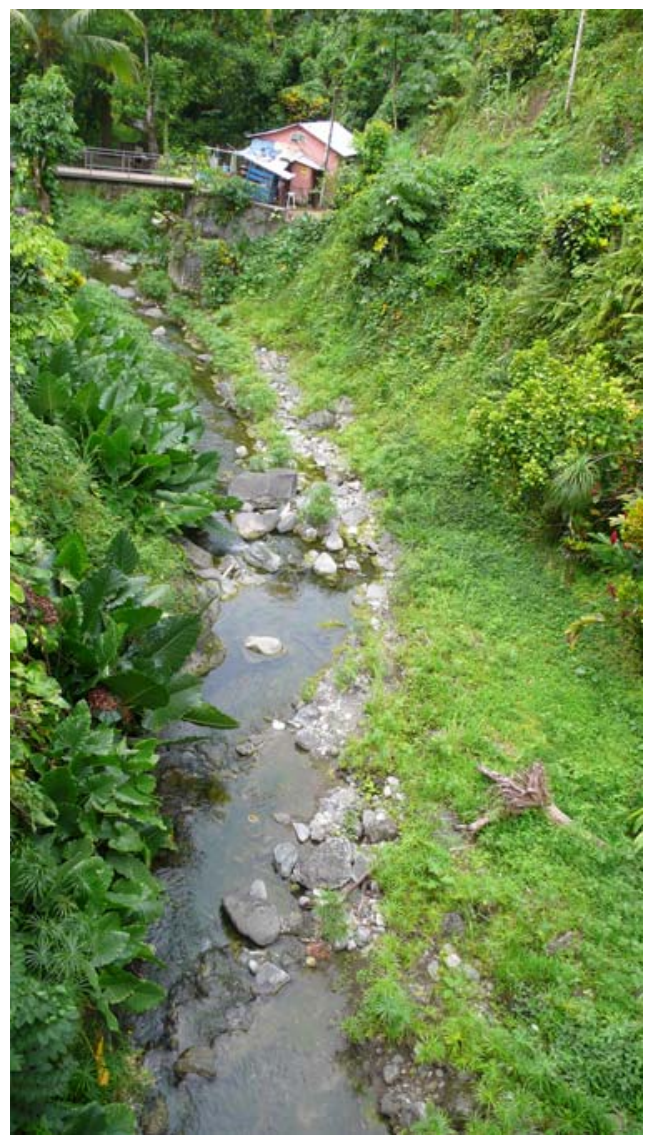

8. Sulphur River Gorge near Bath. Photo by author 
province of St Thomas in the east. After enjoying an ital meal at a Rastafarian restaurant in Port Morant, we arranged a taxi ride up through the village of Bath to the Sulphur River gorge, the site of a hot springs renowned in Jamaica for its healing properties and rumoured to have been discovered by a runaway slave 400 years ago.

We'd planned to stay for a night before hitting the east coast, but the region proved too captivating for a short visit. The Bath Fountain Hotel was built right on the creek in the gorge, with roman bathhouses downstairs and surrounded by luscious visions. A back gate opened onto a path leading up to the magic place where hot water poured out near the base of a Cottonwood Tree, one of two such trees in the immediate area: "one in tree ... tree in one", as I was educated by a local farmer. Outside the hotel, we met Lena, a friendly and outgoing sugar cane farmer who introduces us to Buster who, in his late 60s, shifted a roots tonic concocted from local herbs, performing such from his roadside stall for decades, as his father had before him. A genuine health tonic, but bitter tasting. Buster, who cut us a few jellies (coconuts), presided over a rock pool in the creek below. Featuring a natural water slide, it was full of kids and a welcome respite from the heat.

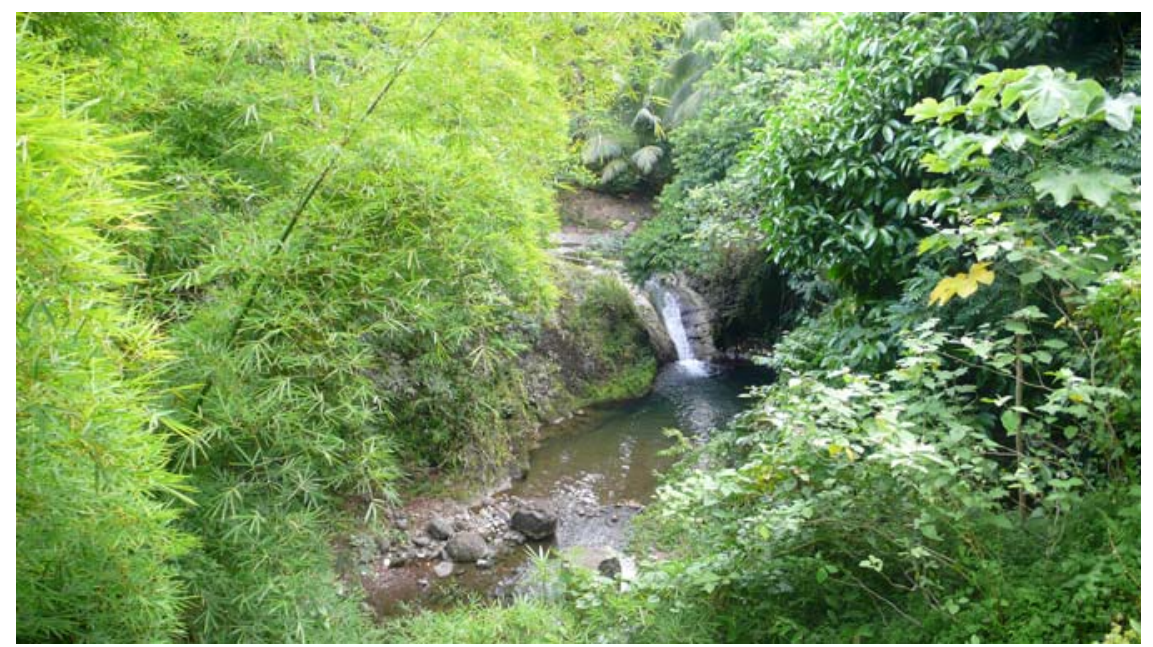

9. Buster's water hole. Photo by author

Temperatures weren't about to grow cooler, though, as we traveled to a couple of diverse bashments, including a smaller party towards Golden Grove in a yard at the Wheeler Field Booster Station on the edge of the sugarcane fields.

Earlier that day, Lena took us on a tour of her farm, her brother Fire Lion sitting outside his shack threading laces in his new white sneakers. He'd be wearing them that night. I also met Latoya, a waitress and short order cook at the hotel, who, as it turns out, is a member of local female dance posse The Trend Setters. Mild mannered waitress by day, voluptuous queen of the cane by night. 


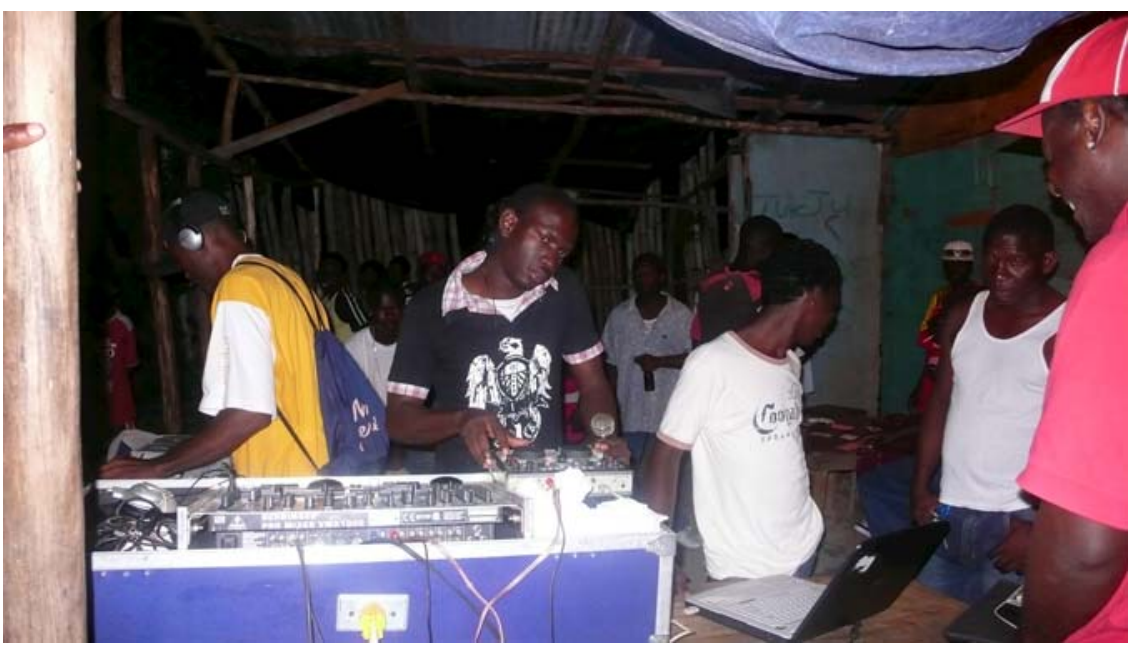

10. Party at Wheeler Field. Photo by author

The following night, Lena and her friends drove us to a party down in Morant Bay. Our driver, Beres, ran low on fuel, and wouldn't deviate for anything, including the dog he collected en route. The bone crunching shriek never warranted so much as a blink from the man at the wheel. Sailing out of the hills into the late evening with the engine turned off to preserve fuel, the car came to a rest in a town where we refueled and warded off an aggressive crack addict. The party attracted a more sophisticated crowd - many women in satin bustieres and fedoras with everything cropped for the eye, men in swanky suits and hats, crates of beer and the locally produced Tia Maria at their feet. Perhaps some had come from the funeral celebrations next door. By comparison to the cane fields party, where the PA fell out a few times and the MC competed with the music, the Morant Bay gig had quality sound and excellent toasters.

At these all-night parties, drawn out and fatigued, I ventured to a crossroads in electronic dance music culture, the home of the rave, if not the term "rave" itself, a possibility entertained by Helen Evans in "Out of Sight, Out of Mind: An Analysis of Rave Culture". But unlike words like "rave" or "jungle", "dancehall" is a fairly innocuous term for a dance music phenomenon, a term that struggles to capture the event it signifies, or the music and dance performed there, its concupiscence and promiscuity incomparable with dance practices in developed countries associated with rave, techno, psytrance and so on. While what became known as "jazz" and "rock \& roll" might have started in the dancehalls that had been the venues at which one's parents performed orthodox dance, what has become one of Jamaica's most notorious exports retains the moniker as a self-identifying label, self-perpetuating in its ambiguous relationship with tradition. (As an aside, at least according to the Wikipedia entry for "Dancehall", apparently the "dance hall" was the term adopted for the cells adjacent to the electric chair at Sing Sing Prison where inmates condemned to death awaited their execution). 
Dancehall music has had a mixed reception in Jamaica. Perhaps the levels of shock, disdain and contempt issuing from some local elites is a reaction to the threat to moral certainties and tradition inscribed in the term "dancehall" itself. At the same time, proponents of dancehall might have received mileage from their subversion of orthodoxy (from toppling the hall of dance) even while instituting another.

Speaking of such. By the end of my second week I was nearing Montego Bay for Sumfest having taken a detour on the beach at Runaway Bay on the north coast over several days.

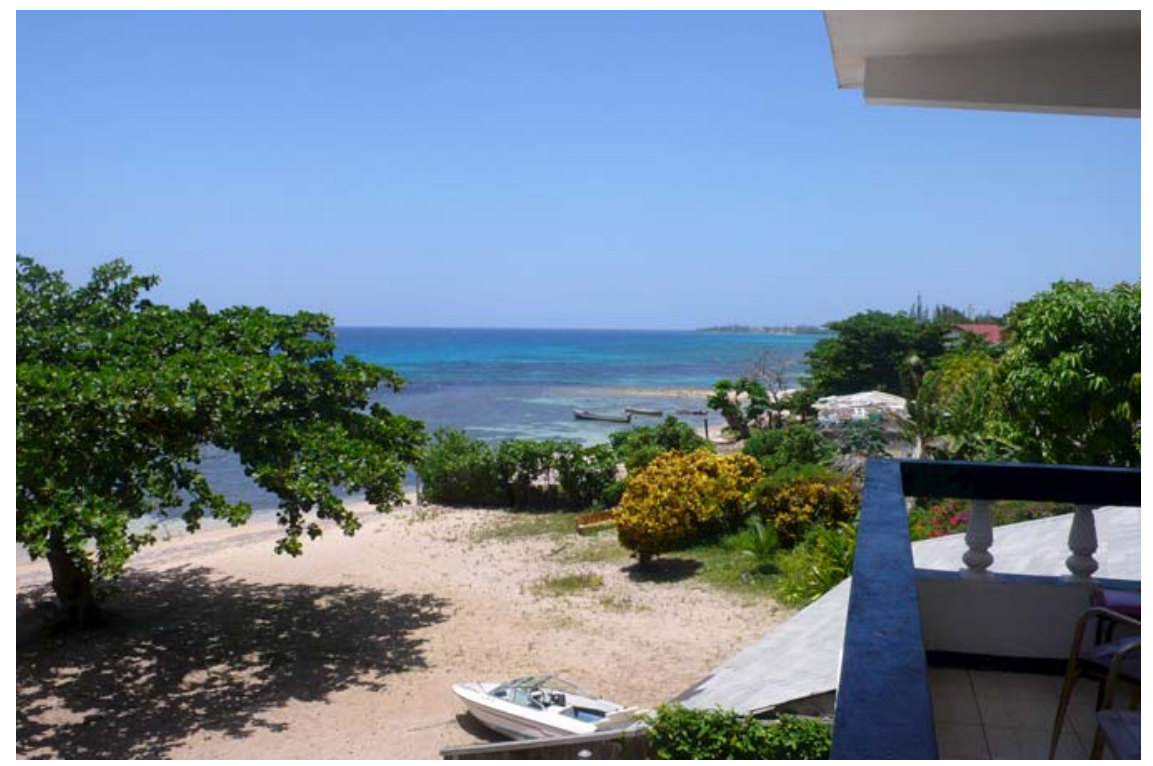

11. The Hotel Nadine at Runaway Bay. Photo by author

Billed as “The Greatest Reggae Show on Earth", the week long Sumfest was in its 16 th year. It was the culmination of my travels on the island and a celebration of the country's musical exports. I made it along to the Dancehall night, a platform for dozens of national heroes who've made it, and are busy making it, into the Dancehall of fame. We had it all, from Anthony B's strident homophobia to the goddess D'Angel who stole the show. But here, where MC superstars are so removed from the audience, where performers are separated from spectators by two VIP corrals, and viewers are cornered by rampant advertising, the concertised Sumfest is a spectacular illustration of how far dancehall may have strayed from its roots (I can't comment on the reggae performances as I did not attend Sumfest on the other nights).

At Sumfest, dancehall was performed on the national stage. It was dancehall's night of the year, a performance for the networks and international audience, but my mind was turned from the 15,000 spectators, and the huge TV audience, to the nightworld of Kingston and beyond, to the events in the streets, yards, canefields and clubs where I'd encountered a people committed to the compulsion of giving it up like everybody's watching. 


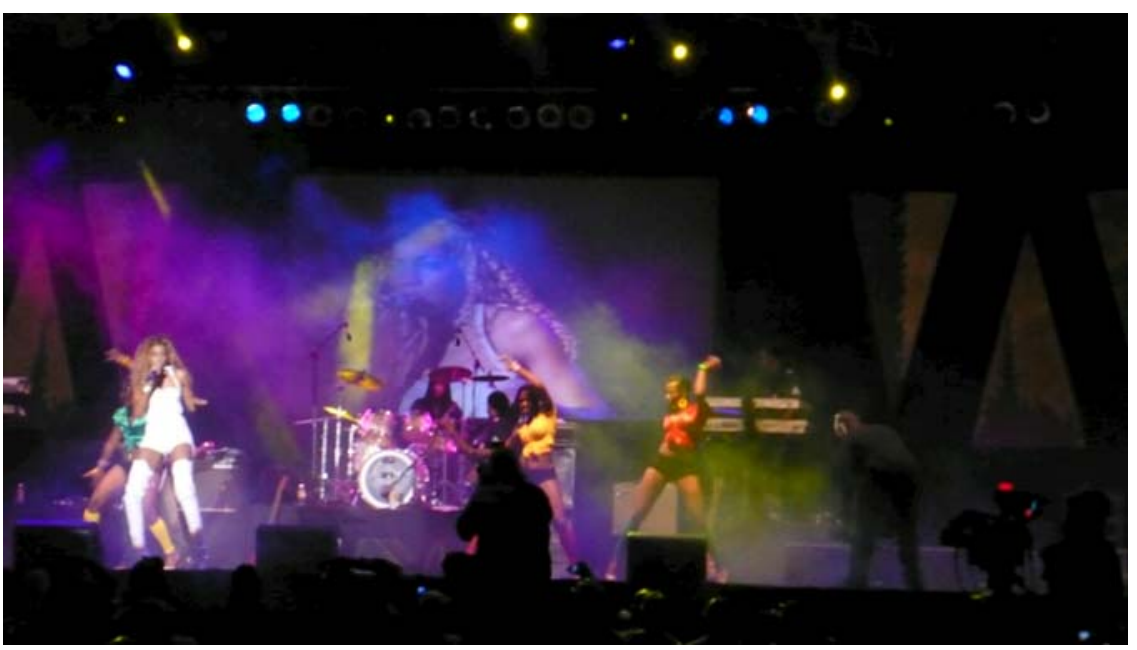

12. D'Angel at Sumfest's Dancehall night. Photo by author

I'd only touched the surface, but it was time to go...

\section{References}

Cooper, Carolyn. 2004. Sound Clash: Jamaican Dancehall Culture at Large. Palgrave Macmillan.

Jones, Simon. 1995. "Rocking the House: Sound System Cultures and the Politics of Space." Journal of Popular Music Studies 7: 1-24.

Murray, Enda. 2001. "Sound Systems and Australian DiY Culture: Folk Music for the Dot Com Generation". In Graham St John (ed), FreeNRG: Notes From the Edge of the Dance Floor, pp 57-70. Common Ground Press: Melbourne. Available as a free downloadable ebook: http://www.edgecentral.net/freenrg.htm.

Partridge, Christopher. 2010. Dub in Babylon. London: Equinox (forthcoming).

Stanley Niaah, Sonjah. 2010. DanceHall: From Slave Ship to Ghetto. University of Ottawa Press. Stolzoff, Norman. 2000. Wake the Town and Tell the People: Dancehall Culture in Jamaica. Duke University Press.

Veal, Michael. 2007. Dub: Soundscapes and Shattered Songs in Jamaican Reggae. Middletown, CT: Wesleyan University Press.

\section{Acknowledgements}

Thanks to Ripley, Andrea Lewis, all the participants in the Uncertain Vibes panel (Hillegonda Rietveld, Anna Gavanas, Joshua Schmidt and Rob Lindop) along with Frank, Bradley, Sophia, Lena. Thanks and congratulations to Sonjah Stanley Niaah for organising the 2008 Crossroads in Cultural Studies conference and luring us all to Jamaica. Thanks also to my generous hosts "Coach" Ted Edwards and Barbara Rose Johnston, Dallas and Erin in Venice Beach, Jay Walsh who maintains San Francisco's best couch, and Kathleen Williamson who maintains the flight deck at Rose Rd.

\section{Notes}

